\title{
Differentiation of Mycobacterium, Nocardia, and Related Taxa by Thin-layer Chromatographic Analysis of Whole-organism Methanolysates
}

\author{
By D. E. MINNIKIN, L. ALSHAMAONY AND M. GOODFELLOW \\ Departments of Organic Chemistry and Microbiology, \\ University of Newcastle, Newcastle upon Tyne $N E_{\mathrm{I}}{ }_{7} R U$
}

(Received 2 December 1974)

\section{INTRODUCTION}

Few simple and reliable tests are available for the differentiation of Mycobacterium, Nocardia and related taxa. There is some evidence to indicate that chemical markers will be useful for the identification of such actinomycetes (Goodfellow, I973; Staneck \& Roberts, 1974).

Lipids characteristic of nocardiae (LCN-As) can be detected by thin-layer chromatographic analysis of ethanol-diethyl ether $(\mathrm{I}: \mathrm{I}, \mathrm{V} / \mathrm{V})$ extracts of nocardiae, true corynebacteria and rhodochrous strains, but are generally absent from mycobacteria, rothiae and actinomadurae (Mordarska, Mordarski \& Goodfellow, 1972; Goodfellow, 1973; Goodfellow et al. 1974). LCN-As have been identified as free mycolic acids (Goodfellow et al. 1973) with the general structural formula:

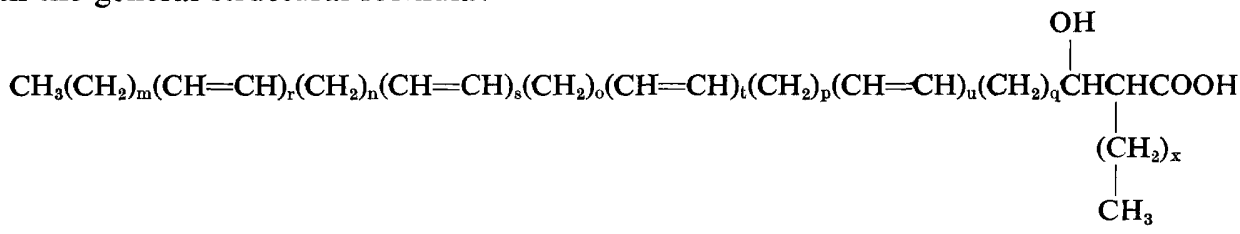

where $\mathrm{r}+\mathrm{s}+\mathrm{t}+\mathrm{u}$ lies between $\mathrm{o}$ and 4 , and $\mathrm{m}, \mathrm{n}, \mathrm{o}, \mathrm{p}$ and $\mathrm{q}$ are all greater than $\mathrm{I}$ (Maurice, Vacheron \& Michel, I97I ; Minnikin, Patel \& Goodfellow, 1974). The mycolic acids from mycobacteria also contain components with oxygen functions, e.g. $>\mathrm{C}=\mathrm{O},>\mathrm{CH}-\mathrm{OCH}_{3}$, $-\mathrm{COOH}$, in addition to the 3 -hydroxyacid unit (Etémadi, 1967). Thin-layer chromatography (t.l.c.) of the methyl esters of the total mycolic acids from mycobacteria can therefore be expected to produce a multiple spot pattern, while those from strains classified in the other taxa should only form a single spot.

This paper demonstrates that the pattern of spots corresponding to mycolic esters obtained on t.l.c. analysis of whole-organism methanolysates provides a means of distinguishing mycobacteria and other taxa containing mycolic acids. The technique is rapid, simple, requires no expensive equipment, and should be applicable in routine clinical laboratories.

\section{METHODS}

Cultures. Most of the reference strains (Table I) were included in earlier studies where detailed strain histories can be found (Goodfellow, I97I, 1973; Goodfellow \& Orchard, 1974; Goodfellow et al. 1974). Working stock cultures of rothiae and corynebacteria were 
maintained on tryptic soy agar (Difco) and on nutrient agar plus I\% (v/v) Tween 80 , respectively. The remaining strains were kept on yeast extract agar.

Cultivation. The rothiae and corynebacteria were grown in tryptic soy broth (Difco) and in nutrient broth plus Tween 80 , respectively, for 2 to 3 days at $37^{\circ} \mathrm{C}$. The remaining strains were also grown in shake flasks but at 30 or $37^{\circ} \mathrm{C}$ for 3 to ro days in modified Sauton's medium (Mordarska et al. 1972). After cultivation, bacteria were harvested by centrifugation, washed with distilled water and freeze-dried.

Whole-cell methanolysis. Dry bacteria (approx. $100 \mathrm{mg}$ ) were mixed with dry methanol $(5 \mathrm{ml})$, toluene $(5 \mathrm{ml})$ and concentrated sulphuric acid $(0.2 \mathrm{ml})$ in a $20 \mathrm{ml}$ tube closed with a PTFE-lined screw cap (Sovirel No. 4.6r I-53, V. A. Howe and Co. Ltd, London). The contents of the tube were mixed thoroughly and methanolysis allowed to proceed for 12 to $\mathrm{I} 6 \mathrm{~h}$ at $50^{\circ} \mathrm{C}$. Initially, tubes were shaken vigorously in a water bath (Buchler Rotary Evapomix), but stationary incubation proved equally successful. The reaction mixture was allowed to cool at room temperature, $2 \mathrm{ml}$ hexane were added, and the mixture was shaken and then allowed to settle. The scale of the procedure can be reduced by a factor of at least 20. A more rapid methanolysis can be achieved by heating the components of the mixture under reflux for $3 \mathrm{~h}$.

Thin-layer chromatography. Samples from the upper layer of the mixture were spotted on thin-layer plates coated with Merck Silica Gel H $(0.5 \mathrm{~mm})$ and the chromatograms developed in petroleum ether (b.p. 60 to $80^{\circ} \mathrm{C}$ )-diethyl ether $(85: 15, \mathrm{v} / \mathrm{v})$. The positions of the separated components were revealed by charring at 150 to $200{ }^{\circ} \mathrm{C}$ after spraying with chromic acid solution $\left(5 \mathrm{~g} \mathrm{~K}_{2} \mathrm{Cr}_{2} \mathrm{O}_{7}\right.$ in $5 \mathrm{ml}$ water, made up to $100 \mathrm{ml}$ with conc. $\mathrm{H}_{2} \mathrm{SO}_{4}$, then diluted ten times with water).

The mycolic esters were distinguished from fatty acids of lower molecular weight by reversibly detecting the spots with iodine vapour, and then redeveloping the chromatogram in methanol-water $(5: 2, \mathrm{v} / \mathrm{v})$ for $6 \mathrm{~h}$. Mycolic esters from all the test strains were immobile in this solvent mixture but a sample of methyl I2-hydroxyoctadecanoate was eluted from the plate.

\section{RESULTS AND DISCUSSION}

The patterns obtained on chromatography of methanolysates of typical strains are shown in Fig. I. The corynebacteria, nocardiae and rhodochrous strains all showed a relatively simple pattern of spots on t.l.c. of their methanolysis products. The components with $\boldsymbol{R}_{\boldsymbol{F}}$ values of 0.1 to 0.5 usually correspond to methyl esters of mycolic acids whereas those with higher $R_{F}$ values (0.8 to $\left.1 \cdot 0\right)$ are attributable to the methyl esters of non-hydroxylated fatty acids and in some cases to other long-chain components as yet uncharacterized. When chromatograms were washed with a mixture of methanol-water $(5: 2, \mathrm{v} / \mathrm{v})$, all spots, with the exception of those corresponding to the mycolic esters, were removed. A wash with pure methanol, as used for the detection of free mycolic acids (LCN-As) (Mordarska et al. 1972), eluted the mycolic esters from the corynebacteria and from some rhodochrous strains.

The mycolic esters from the nocardiae were characteristically slightly more mobile than those of the rhodochrous strains, which in turn ran a little faster than those from the corynebacteria studied (Fig. I, and Table I, groups A, B and C). The patterns obtained from the gordonae (Table I, group D) contained minor components (Fig. I) which were not eluted on washing the chromatogram with methanol-water $(5: 2, \mathrm{v} / \mathrm{v})$. Preliminary studies on the nature of these components suggest that they were not mycolic esters. Faint spots were occasionally seen in the patterns obtained from certain nocardiae (Fig. I, NI4, N233) but these components were removed after treatment with the methanol-water mixture. 


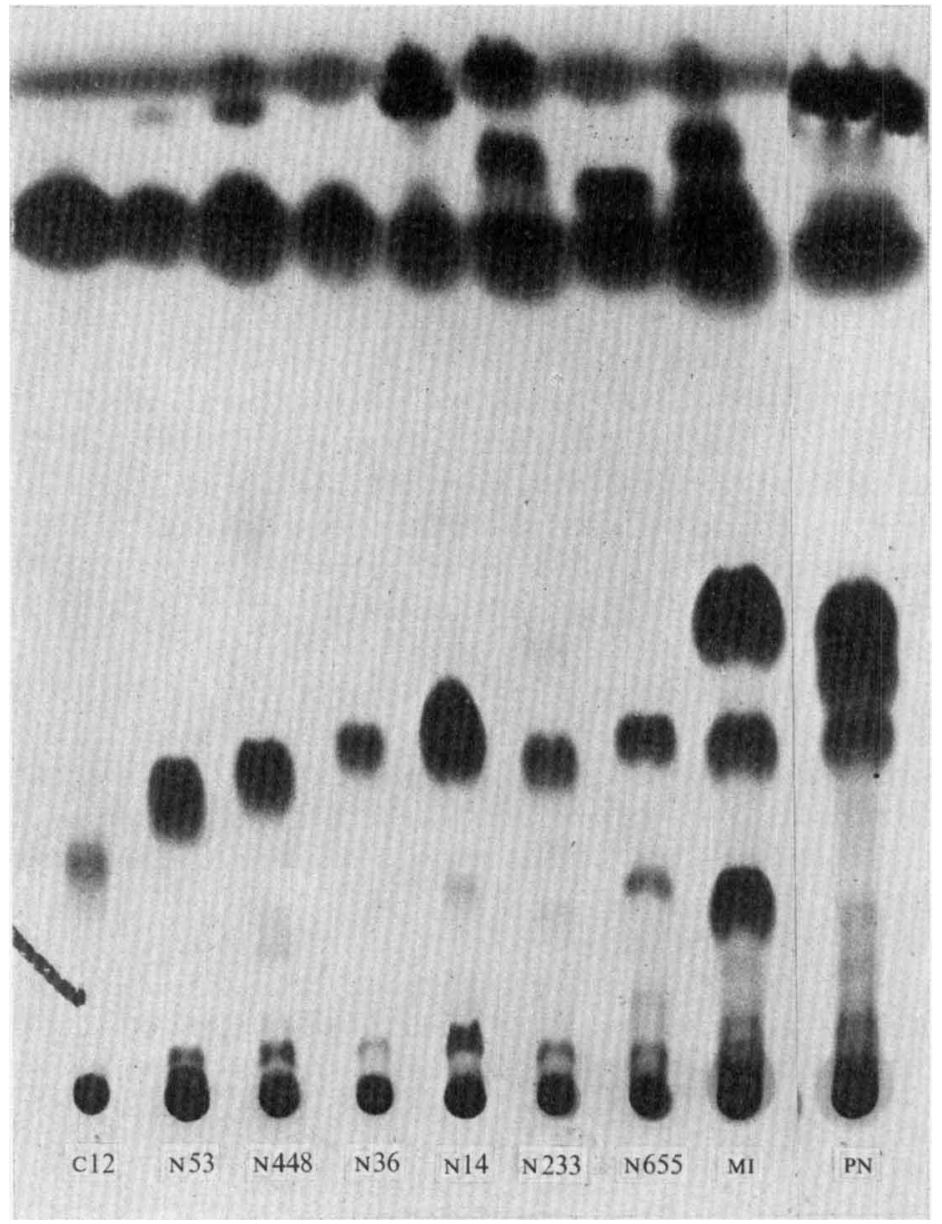

Fig. I. Thin-layer chromatography of whole-organism methanolysates of selected bacteria. Abbreviations: CI2, Corynebacterium bovis; N53 and N448, 'rhodochrous' strains; N36, NI4 and N233, Nocardia caviae, N. brasiliensis and N. asteroides, respectively; N655, Gordona rubra; MI, Mycobacterium intracellulare; PN, Mycobacterium tuberculosis.

The methanolysates from the mycobacteria gave two distinct patterns on t.l.c. One set of strains (Table I, group E) gave a pattern similar to that shown for Mycobacterium intracellulare (Fig. I); the spots corresponded, in order of increasing mobility, to carbomethoxymycolates, ketomycolates and mycolates having no oxygen functions in addition to the 3 hydroxyester grouping (Etémadi, I967; Kusamran, Polgar \& Minnikin, 1972). Mycobacterium tuberculosis and $M$. bovis (Table I, group F) produced methoxymycolates but no carbomethoxymycolates (Etémadi, 1967; Minnikin \& Polgar, 1967a, b). Actinomycetes which did not contain any mycolic acids (Table I, group G) gave a single spot of high $R_{F}$ on t.l.c.

The technique described complements other chemotaxonomic methods involving lipid analyses (Kanetsuna \& Bartoli, 1972; Mordarska et al. 1972; Lechevalier, Lechevalier \& Horan, 1973). Our studies are being extended to include many other strains, to ascertain the complete reliability of the methanolysis technique. It is evident, however, that the method 
Table I. Reference cultures, strain designations and sources

\begin{tabular}{|c|c|c|}
\hline Group A & No. & Strain designation/source \\
\hline Corynebacterium bovis & I & $\mathrm{CI} 2$ \\
\hline C. xerosis & $\mathbf{I}$ & NCTC9755 \\
\hline $\begin{array}{l}\text { Group B } \\
\text { 'Rhodochrous' strains }\end{array}$ & I I & N5, NII, N3I, N38, N53, N6I, N146, N325, N446, N448, R7I \\
\hline $\begin{array}{l}\text { Group C } \\
\quad \text { Nocardia asteroides } \\
N . \text { brasiliensis } \\
N . \text { caviae }\end{array}$ & $\begin{array}{l}3 \\
3 \\
3\end{array}$ & $\begin{array}{l}\text { N13, N233, N317 } \\
\text { NI4, N48, N318 } \\
\text { N36, N23I, N3I } 3\end{array}$ \\
\hline $\begin{array}{l}\text { Group D } \\
\text { Gordona bronchialis } \\
\text { G. rubra } \\
\text { G. terrae }\end{array}$ & $\begin{array}{l}2 \\
2 \\
2\end{array}$ & $\begin{array}{l}\text { N66o, N66I } \\
\text { N655, N658 } \\
\text { N656, N662 }\end{array}$ \\
\hline $\begin{array}{l}\text { Group } \mathrm{E} \\
\text { Mycobacterium avium } \\
\text { M. intracellulare } \\
M . \text { johnei } \\
\text { M. marianum } \\
\text { M. phlei }\end{array}$ & $\begin{array}{l}\text { I } \\
\text { I } \\
\text { I } \\
\text { I } \\
\text { I }\end{array}$ & $\begin{array}{l}\text { D4* } \\
\text { MI* } \\
36 \text { IF* } \\
\text { Mi } 85 \text { (J. Stanford, Middlesex Hospital, London) } \\
\text { M60 }\end{array}$ \\
\hline $\begin{array}{l}\text { Group F } \\
\text { Mycobacterium bovis } \\
\text { M. tuberculosis }\end{array}$ & $\begin{array}{l}\text { I } \\
\text { I }\end{array}$ & $\begin{array}{l}\text { отто strain* } \\
\text { PN strain* }\end{array}$ \\
\hline $\begin{array}{l}\text { Group } \mathrm{G} \\
\text { Actinomadura dassonvillei } \\
\text { A. madurae } \\
\text { A. pelletieri } \\
\text { Rothia dentocariosa } \\
\text { Saccharopolyspora hirsuta } \\
\text { Streptomyces somaliensis }\end{array}$ & $\begin{array}{l}2 \\
5 \\
5 \\
8 \\
4 \\
4\end{array}$ & $\begin{array}{l}\text { N238, N287 } \\
\text { NI7, N35, N304, A22 (IP725), A25 (IP393) } \\
\text { NI8, AI8/AI9/A20 (NCTC3026, 4I62, 999), A37 (CBS708.70) } \\
\text { BI-B8 } \\
\text { N6I 7, N6I8, N622, N623 } \\
\text { A26-A29 (IP395, 702, 3I3, 3I4) }\end{array}$ \\
\hline
\end{tabular}

CBS, Centraalbureau voor Schimmelcultures, Baarn, The Netherlands. IP, Institut Pasteur de Paris, Paris XV, France. NCTC, National Collection of Type Cultures, London.

* Freeze-dried bacteria from Central Veterinary Laboratory, New Haw, Weybridge, Surrey.

described will be of value in distinguishing most mycobacteria and nocardiae from related taxa, and all of these organisms from actinomycetes which do not contain mycolic acids.

The authors thank Grace Alderson for her help, and Mr H. B. Lee, Central Veterinary Laboratory, Weybridge, for the freeze-dried mycobacteria. One of us (L.A.) is grateful for support from the Gulbenkian Foundation and the University of Mosul, Iraq.

\section{REFERENCES}

ETÉMADI, A. M. (1967). Corrélations structurales et biogénétiques des acides mycoliques en rapport avec la phylogenèse de quelques genres d'actinomycetales. Bulletin de la Société de Chimie Biologique 49, 695-706.

Goodfellow, M. (1971). Numerical taxonomy of some nocardioform bacteria. Journal of General Microbiology 69, 33-80.

Goodfellow, M. (1973). Characterisation of Mycobacterium, Nocardia, Corynebacterium and related taxa. Annales de la Société Belge de Médecine Tropicale 53, 287-298.

Goodfellow, M., Lind, A., Mordarska, H., Pattyn, S. \& Tsukamura, M. (I974). A co-operative numerical analysis of cultures considered to belong to the 'rhodochrous' complex. Journal of General Microbiology 85, 291-302. 
Goodfellow, M., Minnikin, D. E., Patel, P. V. \& Mordarska, H. (1973). Free nocardomycolic acids in the classification of nocardias and strains of the 'rhodochrous' complex. Journal of General Microbiology 74, I 85-I 88 .

Goodfellow, M. \& Orchard, V. A. (1974). Antibiotic sensitivity of some nocardioform bacteria and its value as a criterion for taxonomy. Journal of General Microbiology 83, 375-387.

Kanetsuna, F. \& Bartoli, A. (1972). A simple chemical method to differentiate Mycobacterium from Nocardia. Journal of General Microbiology 70, 209-2 12.

Kusamran, K., Polgar, N. \& Minnikin, D. E. (1972). The mycolic acids of Mycobacterium phlei. Chemical Communications 1972, I I I-I I2.

Lechevalier, M. P., Lechevalier, H. \& Horan, A. C. (1973). Chemical characteristics and classification of nocardiae. Canadian Journal of Microbiology r9, 965-972.

Maurice, M. T., Vacheron, M. J. \& Michel, G. (197I). Isolement d'acides nocardiques de plusieurs espèces de Nocardia. Chemistry and Physics of Lipids 7, 9-18.

Minnikin, D. E., Patel, P. V. \& Goodfellow, M. (I974). Mycolic acids of representative strains of Nocardia and the 'rhodochrous' complex. FEBS Letters 39, 322-324.

Minnikin, D. E.\& Polgar, N. (1967a). The mycolic acids from human and avian tubercle bacilli. Chemical Communications 1967, 916-9I8.

Minnikin, D. E. \& Polgar, N. (1967 b) The methoxymycolic and ketomycolic acids from human tubercle bacilli. Chemical Communications 1967, $1172-1174$.

Mordarska, H., Mordarski, M. \& Goodfellow, M. (1972). Chemotaxonomic characters and classification of some nocardioform bacteria. Journal of General Microbiology 71, 77-86.

Staneck, J. L. \& Roberts, G. D. (1974). Simplified approach to identification of aerobic actinomycetes by thin-layer chromatography. Applied Microbiology 28, 226-23I. 